\title{
Kesehatan Mental Siswa SMP-SMA Indonesia Selama Masa Pandemi dan Faktor Penyebabnya
}

\author{
Sendi Etika Addini ${ }^{1}$, Bina Decilena Syahidah ${ }^{2}$, Betania Arinda Putri ${ }^{3}$, Hari \\ Setyowibowo ${ }^{4}$ \\ ${ }^{1,2,3,4}$ Departemen Psikologi Pendidikan, Fakultas Psikologi Universitas Padjadjaran \\ Jln. Raya Bandung-Sumedang KM 21, Sumedang, Indonesia 45363 \\ 1,2,3,4 Pusat Studi dan Inovasi Fakultas Psikologi Universitas Padjadjaran \\ Jln. Raya Bandung-Sumedang KM 21, Sumedang, Indonesia 45363 \\ sendi11001@mail.iunpad.ac.id
}

Abstrak

\begin{abstract}
Kesehatan mental pada remaja merupakan permasalahan penting yang perlu diperhatikan. Pandemi COVID-19 membuat permasalahan ini menjadi semakin perlu mendapatkan perhatian serius dari para pemangku kepentingan, terutama terkait dengan implementasi kebijakan Pembelajaran Jarak Jauh (PJJ). Hasil penelitian sebelumnya menunjukkan adanya sejumlah keluhan dari siswa terkait pelaksanaan PJJ. Oleh karena itu penelitian ini dilakukan dengan tujuan untuk memberikan gambaran deskriptif tingkat depresi dan kecemasan pada siswa SMP dan SMA yang sedang menjalani PJJ serta mendeskripsikan beberapa faktor-faktor yang dipersepsikan mengganggu bagi para siswa dan potensial untuk menjadi penyebab kondisi tersebut. Penelitian ini menggunakan desain non-eksperimental deskriptif kuantitatif dengan melibatkan 629 orang siswa SMP dan SMA di Indonesia yang menjalani PJJ. Pengambilan data dilakukan dengan menggunakan Patient Health Questionaire (PHQ-9), Generalized Anxiety Disorder (GAD-7) dan survey mengenai beberapa faktor yang dirasa mengganggu bagi siswa. Kuisioner diisi secara daring dan statistik deskriptif digunakan untuk menganalisis data. Hasil penelitian menunjukkan sebanyak $46 \%$ siswa mengalami gejala kecemasan dan 58\% mengalami gejala depresi. Adapun faktor-faktor yang perlu untuk diperhatikan dalam kondisi ini adalah terkait akademik dan interaksi sosial siswa terutama dengan teman. Penelitian lebih lanjut diperlukan untuk menjelaskan mengenai pengaruh yang diberikan oleh pandemi serta hubungan faktor akademik dan sosial terhadap kondisi kesehatan mental siswa.
\end{abstract}

Kata kunci: COVID-19; Depresi; Kecemasan; Kesehatan Mental Siswa; Pembelajaran Jarak Jauh;

\begin{abstract}
Adolescent's mental health was an important issue that needs serious attention. Pandemic COVID-19 makes these issues need more attention from stakeholders, especially the implementation of Pembelajaran Jarak Jauh (PJJ) policy. Previous study showed that there were some complaints from students regarding of the implementation of PJJ policy. Terefore this study aimed to describe middle and senior high student's mental health during PJJ and which factors potentially were the cause of these problems. This study used non-experimental dscripptive quantitative design. 629 middle and high school students in Indonesia were participating in this study. Patient Health Questionaire (PHQ-9), Generalized Anxiety Disorder (GAD-7) and a survey about some factors that considered disturbing to student was used for this study. Online questionnaire and descriptive statistics were used to collect and analyze the data. Result showed $46 \%$ students undergoing anxiety symptoms and 58\% shows depression symptoms. Academic and social factors, especially interaction with friends as factors that need to be noticed when discussing student's mental health during the pandemic. Further research is needed to explain the impact of the pandemic and how those factors can affect student's mental health.
\end{abstract}

Keywords: Anxiety; COVID-19; Depression; Distance Education; Student's Mental Health

\section{PENDAHULUAN}

Isu mengenai kesehatan mental siswa jenjang pendidikan SMP dan SMA, merupakan isu yang menarik perhatian, sebab perilaku belajar yang baik didorong oleh kondisi mental yang sehat, baik, atau normal. (Lusi et al., 2009). Peserta didik yang memiliki permasalahan terkait dengan 
kesehatan mental akan menunjukkan prestasi belajar yang tidak maksimal (Lusi et al., 2009). World Health Organization (WHO) mencatat bahwa sebanyak 16\% dari permasalahan kesehatan dunia berkaitan dengan kondisi kesehatan mental pada remaja usia 10-19 tahun. Selain itu, sebagian permasalahan kesehatan mental mulai muncul pada usia 14 tahun tetapi kebanyakan kasus tidak terdeteksi dan tidak tertangani (WHO, 2020). Hal ini juga didukung oleh pernyataan National Alliance of Mental Health yang menyatakan bahwa 50\% gangguan kesehatan mental permanen dimulai saat seseorang berusia 14 tahun (Ali \& Karyani, 2015). Secara global, permasalahan kesehatan mental yang paling banyak dialami kalangan remaja adalah depresi (Juliawan et al., 2020; WHO, 2020).

Di Indonesia, hasil Riset Kesehatan Dasar (Riskesdas) yang dilakukan oleh Kementrian Kesehatan RI tahun 2015 menunjukkan 6\% prevalensi gangguan emosional dialami oleh remaja usia 15 tahun ke atas (Ali \& Karyani, 2015). Hasil penelitian lain menunjukkan 60,17\% siswa SMP-SMA mengalami gangguan mental emosional, seperti kesepian $(44,54 \%)$, kecemasan $(40,75 \%)$, dan intensi bunuh diri (7,33\%) (Mubasyiroh et al., 2017). Kemudian, di tahun 2018, hasil Riskesdas menunjukkan prevalensi gangguan depresi dan emosional pada kelompok usia 1524 tahun mencapai 157.695 orang (Kementrian Kesehatan Republik Indonesia, 2018). Data-data di atas menunjukkan bahwa isu mengenai kesehatan mental siswa yang akan mempengaruhi hasil belajar merupakan isu yang penting untuk diperhatikan,

Kondisi pandemi Covid-19 juga menjadi salah satu faktor yang mempengaruhi kesehatan mental siswa. Sejarah mencatat kondisi pandemi akan memberikan dampak negatif pada kondisi psikologis masyarakat, terutama pada anak-anak dan remaja yang umumnya lebih rentan mengalami permasalahan psikologis (Akat \& Karataş, 2020). Hal ini dikarenakan belum matangnya fungsi kognitif serta emosi membuat mereka kesulitan untuk memahami situasi yang terjadi dan mengekspresikan emosinya dengan tepat (Akat \& Karataş, 2020).

Pandemi Covid-19 juga mempengaruhi jalannya proses pendidikan di Indonesia. Dalam rangka mematuhi protokol kesehatan yang telah ditetapkan pemerintah, seluruh sekolah diharuskan untuk tidak melakukan pembelajaran secara langsung (tatap muka) dan menjalani Pembelajaran Jarak Jauh (PJJ). Selama menjalani PJJ, siswa mengalami banyak perubahan dalam proses belajarnya, yang mana hal ini menyebabkan anak merasa bosan dan ingin segera kembali beraktifitas di sekolah (Wahana Visi Indonesia, 2020).

Beberapa hasil penelitian mengenai kondisi siswa di Indonesia sudah dipublikasikan selama masa pandemi Covid-19. Penelitian-penelitian tersebut menemukan terdapat berbagai keluhan dari siswa terutama berkaitan dengan PJJ. Sebagian besar hasil penelitian berfokus pada evaluasi siswa terhadap pelaksanaan PJJ (KPAI, 2020; Murhadi \& Ponidi, 2020; Oktawirawan, 2020; Wahana Visi Indonesia, 2020). Akan tetapi masih minim penelitian yang membahas secara bersamaan mengenai gambaran kesehatan mental siswa dan hal-hal apa saja yang dirasa mengganggu dalam kehidupan sehari-hari siswa selama menjalani PJJ. Oleh karena itu, penelitian ini dilakukan untuk melihat gambaran kondisi kesehatan mental siswa yang diukur melalui tingkat kecemasan dan gejala depresi yang dialami setelah 8 bulan menjalani PJJ serta mengetahui hal apa saja yang dirasa mengganggu bagi siswa SMP-SMA selama pandemi Covid-19.

\section{METODE}


Penelitian ini merupakan penelitian Non-Eksperimental dengan menggunakan metode penelitian Deskriptif Kuantitatif, yaitu desain penelitian yang bertujuan untuk memberikan gambaran yang akurat tentang karakteristik suatu situasi atau fenomena (Johnson \& Christensen, 2017). Populasi dari penelitian ini adalah seluruh siswa SMP dan SMA se-Indonesia yang menjalani PJJ. Data statistik nasional tahun 2019 mencatat jumlah siswa SMP dan SMA yang terdaftar mencapai 19,8 juta orang (Badan Pusat Statistik, 2019). Berdasarkan penghitungan statistik dan menggunakan rumus penetapan jumlah sampel yang dipublikasikan oleh divisi penelitian The National Education Association (Johnson \& Christensen, 2017; Krejcie \& Morgan, 1970), sampel minimal dalam penelitian ini adalah 384 orang dengan menggunakan teknik convenience sampling.

Pengambilan sampel kemudian dilakukan dengan membagikan tautan pengisian kuisioner online kepada orang tua calon partisipan melalui pesan chat. Bagi siswa yang tidak bersedia berpartisipasi juga akan langsung diarahkan pada halaman penutup. Sehingga dalam penelitian diperoleh 629 orang sampel yang mengisi sesuai dengan syarat, yaitu mengisi penuh setiap item terkait gejala depresi dan kecemasan.

Alat ukur yang digunakan dalam penelitian ini adalah Patient Health Questionaire (PHQ-9) dan Generalized Anxiety Disorder (GAD-7) versi bahasa Indonesia. PHQ-9 dan GAD-7 sendiri merupakan alat ukur depresi dan kecemasan yang dapat digunalakn pada populasi umum (seperti Nazari et al., 2021). Alat ukur PHQ-9 versi bahasa Indonesia dilaporkan memiliki nilai reliabilitas di atas 0,8 (Larasati et al., 2020; Onie et al., 2020) dan validitas yang memuaskan (Onie et al., 2020). Demikian pula dengan pengujian GAD-7 versi bahasa Indonesia yang menunjukkan reliabilitas di atas 0,8 (Budikayanti et al., 2019; Onie et al., 2020) dan koefisien validitas 0,847 (Budikayanti et al., 2019). PHQ-9 digunakan untuk menggambarkan gejala depresi yang dimiliki oleh siswa dan GAD-7 digunakan untuk mengukur gejala kecemasan.

Alat ukur PHQ terdiri dari sembilan item berupa pernyataan terkait suatu suatu kondisi yang menggambarkan gejala-gejala depresi. Masing-masing item dinilai oleh siswa seberapa sering kondisi tersebut dirasakan/dialami dalam 2 minggu terakhir. Penilaian terdiri dari 4 skala (1=tidak pernah; 2=beberapa hari; 3=lebih dari 7 hari; 4=hampir setiap hari. Kemudian jawaban dinilai dengan nilai 0-3 (tidak pernah=0; beberapa hari $=1$; lebih dari 7 hari=2; hampir setiap hari=3). Dengan demikian PHQ akan memiliki nilai rentang skor total 0-27 yang dikelompokkan pada kategori yang telah ditetapkan (Kroenke \& Spitzer, 2002), yaitu:

a. $0-4=$ Tidak Ada Gejala

b. $5-9=$ Ringan

c. $10-14=$ Sedang

d. $15-19=$ Agak Berat

e. $20-27=$ Berat

Sementara alat ukur GAD terdiri atas tujuh item berupa pernyataan terkait suatu suatu kondisi yang menggambarkan gejala-gejala kecemasan. Masing-masing item dinilai oleh siswa seberapa sering kondisi tersebut dirasakan/dialami dalam dua minggu terakhir.

Skala jawaban dan penilaian akan jawaban dilakukan sama seperti alat ukur PHQ. Sehingga, alat ukur GAD akan akan memiliki nilai rentang skor total 0-21 yang dikelompokkan pada kategori yang telah ditetapkan (Spitzer RL et al., 2006), yaitu: 

a. $0-4=$ Tidak Ada Gejala
b. $5-9=$ Ringan
c. $10-14=$ Sedang
d. $15-21=$ Berat

Untuk mengetahui mengenai hal-hal yang dirasa mengganggu dan berpotensi menjadi sumber yang menyebabkan gangguan pada kesehatan mental siswa, tim peneliti merancang survey berdasarkan pada beberapa penelitian sebelumnya. Berdasarkan salah satu penelitian yang telah dilakukan pada kelompok mahasiswa, terdapat 4 kelompok besar yang menjadi sumber stress bagi siswa/remaja selama pandemi COVID-19, yaitu terkait kesehatan, akademik, sosial, dan finansial (Son et al., 2020). Selain itu, pada beberapa penelitian lain juga telah digambarkan beberapa permasalahan spesifik yang dialami oleh siswa SMP-SMA selama menjalani PJJ (KPAI, 2020; Murhadi \& Ponidi, 2020; Oktawirawan, 2020; Wahana Visi Indonesia, 2020). Mengacu pada penelitian-penelitian di atas, maka dirancang 12 pernyataan mengenai beberapa hal-hal yang berpotensi mengganggu siswa (seperti "Kekhawatiran akan kondisi kesehatan diri sendiri"). Setiap pernyataan dinilai berdasarkan seberapa mengganggu kondisi tersebut bagi siswa dengan menggunakan skala 1-4 (1=tidak mengganggu sama sekali; 2=agak mengganggu; 3=cukup mengganggu; 4=sangat mengganggu). Jawaban yang diberikan kemudian akan dikodekan sesuai dengan kode pilihan jawaban. Kemudian akan dianalisis jumlah siswa yang menjawab pada masing-masing pilihan jawaban di setiap item.

\section{HASIL}

Dalam penelitian ini diperoleh responden sebanyak 629 orang siswa SMP dan SMA. Adapun data demografis partisipan tertuang dalam Tabel 1.:

\section{Tabel 1.}

Data Demografis Partisipan

\begin{tabular}{cccc}
\hline & & Jumlah & $\mathbf{\%}$ \\
\hline \multirow{2}{*}{ Jenis Kelamin } & Perempuan & 423 & $67,25 \%$ \\
& Laki - laki & 206 & $32,75 \%$ \\
\hline \multirow{2}{*}{ Jenjang Pendidikan } & SMP & 211 & $33,55 \%$ \\
& SMA & 418 & $66,45 \%$ \\
\hline
\end{tabular}

Berdasarkan data demografis pada Tabel 1, dapat diketahui bahwa partisipan dalam penelitian ini didominasi oleh jenis kelamin perempuan dan jenjang pendidikan SMA. Adapun sebaran partisipan berdasarkan asal provinsi cukup meluas. Partisipan dalam penelitian ini berasal dari 18 provinsi dan 6 kepulauan (Sumatera, Jawa, Nusa Tenggara-Bali, Kalimantan, Sulawesi, dan Maluku).

Pengukuran kesehatan mental siswa dalam penelitian ini diukur melalui gambaran gejala kecemasan dan gejala depresi yang dialami. Hasil pengukuran gejala kecemasan siswa digambarkan melalui Grafik 1. dan gejala depresi siswa digambarkan melalui Grafik 2. 


\section{Gejala Kecemasan}

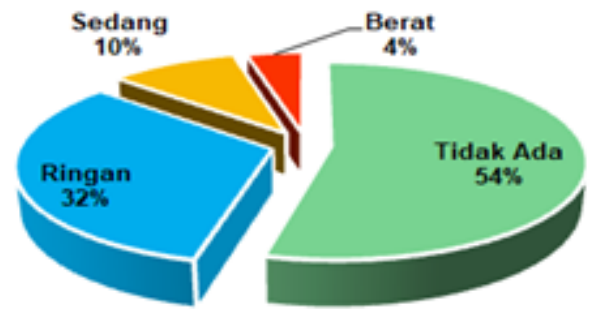

\section{Grafik 1. Persentase Gejala Kecemasan Siswa SMP-SMA di Indonesia}

Grafik 1 menunjukkan bahwa lebih dari 50\% siswa SMP-SMA di Indonesia pada dasarnya tidak menunjukkan adanya permasalahan terkait gejala kecemasan. Akan tetapi perlu diperhatikan bahwa terdapat $4 \%$ siswa yang telah menunjukkan gejala kecemasan berat dan $10 \%$ menunjukkan gejala kecemasan sedang.

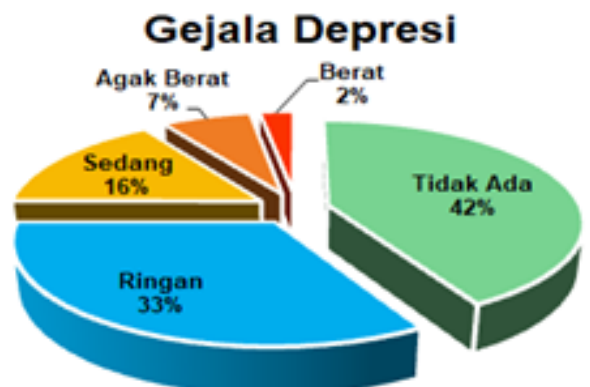

\section{Grafik 2. Persentase Gejala Depresi Siswa SMP-SMA di Indonesia}

Sementara untuk gambaran mengenai gejala depresi menunjukkan sebagian besar siswa menunjukkan adanya gejala depresi. Sebanyak 25\% siswa SMP-SMA di Indonesia telah menunjukkan adanya gejala depresi sedang hingga berat.

Tim peneliti juga berusaha menggambarkan hal-hal yang dirasa mengganggu bagi siswa selama menjalani PJJ di masa pandemi yang tergambar melalui grafik berikut : 
Psychopolytan : Jurnal Psikologi

ISSN CETAK : : 2614-5227

VOL. 5 No. 2, Februari 2022

ISSN ONLINE : :2654-3672

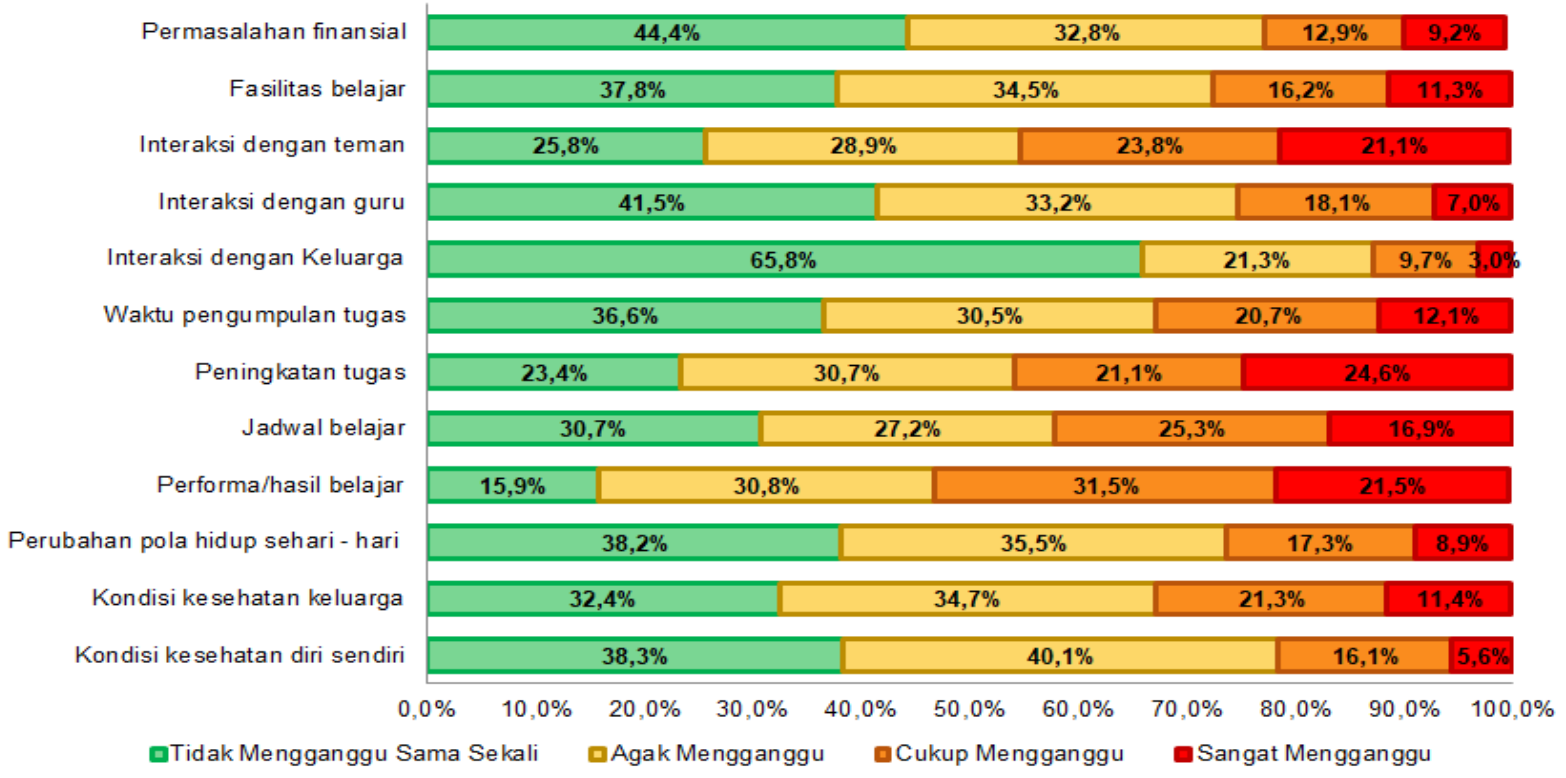

Grafik 3. Hal - hal yang dirasa mengganggu oleh siswa SMP-SMA di Indonesia

Melalui grafik di atas dapat diketahui bahwa pada siswa SMP dan SMA di Indonesia, terdapat beberapa hal yang dirasa cukup mengganggu hingga sangat mengganggu bagi kehidupan seharihari siswa. Hal-hal tersebut adalah :

1. Kekhawatiran siswa terkait performa atau hasil belajarnya selama PJJ (31,5\% merasa cukup terganggu dan $21,5 \%$ sangat terganggu)

2. Banyaknya jumlah tugas yang diperoleh dari sekolah $(21,1 \%$ merasa cukup terganggu dan $24,6 \%$ sangat terganggu)

3. Jadwal belajar/kelas (25,3\% merasa cukup terganggu dan $16,5 \%$ sangat terganggu)

4. Terbatasnya interaksi dengan teman $(23,8 \%$ merasa cukup terganggu dan $21,1 \%$ sangat terganggu)

\section{DISKUSI}

Sebagaimana hasil penelitian di atas, dapat diketahui bahwa selama menjalani pembelajaran jarak jauh sebanyak 46\% siswa telah menunjukkan gejala kecemasan dengan tingkat yang berbeda. Secara rinci, sebanyak 32\% siswa SMP dan SMA telah menunjukkan gejala kecemasan yang tergolong rendah, 10\% gejala kecemasan sedang, dan 4\% gejala kecemasan yang tergolong berat.

Jika menilik kembali perkembangan kondisi kesehatan mental remaja di Indonesia, data Riskesdas RI telah menunjukkan prevalensi gangguan mental emosional remaja yang mencapai 10\% (Kementrian Kesehatan Republik Indonesia, 2018; Pusat Data dan Informasi Kementrian Kesehatan RI, 2019). Penelitian lain juga menunjukkan bahwa 40,75\% siswa SMP dan SMA melaporkan merasa cemas (Mubasyiroh et al., 2017). Tidak hanya sebelum pandemi, beberapa penelitian yang telah dilakukan selama pandemi juga menunjukkan sebagian besar remaja mengalami kecemasan yang tergolong sedang hingga tinggi (Fitria \& Ifdil, 2020; Suryaatmaja \& Wulandari, 2020).

Dengan memperhatikan hasil penelitian ini dan beberapa penelitian lain, baik sebelum dan selama pandemi berlangsung, dapat diketahui bahwa kondisi gejala kecemasan remaja, terutama 
pada jenjang SMP dan SMA, menujukkan persentase yang perlu untuk semakin diperhatikan. Di mana sebagian telah menunjukkan gejala kecemasan yang tergolong sedang hingga berat.

Selain itu, siswa juga menunjukkan gejala depresi yang bervariasi. Sebanyak 58\% siswa SMP dan SMA di Indonesia telah menunjukkan gejala depresi ringan dan sebanyak 25\% siswa SMP dan SMA telah menunjukkan gejala depresi yang tergolong sedang hingga berat. Hal ini menunjukkan bahwa sudah cukup banyak siswa SMP dan SMA yang cukup terganggu dengan kondisi pandemi ini dan mungkin membutuhkan bantuan yang serius dari berbagai pihak seperti pihak sekolah dan keluarga. Di mana penelitian menunjukkan bahwa kesejahteraan mental siswa dapat ditingkatkan melalui kerja sama sekolah dan keluarga (Smith et al., 2020).

Meskipun jumlah siswa yang mengalami gejala kecemasan dan depresi yang tergolong rendah masih lebih banyak, kemungkinan resiko kondisi tersebut akan semakin parah jika tidak dilakukan pencegahan dengan baik. Selain itu, anak yang memiliki kedua gejala akan memiliki kemungkinan menunjukkan gejala yang semakin berat (Bernstein, 1991). Artinya, akan sangat mungkin bagi anak yang memiliki gejala depresi dan kecemasan rendah untuk kemudian meningkat menjadi kategori sedang atau bahkan tinggi. Kecemasan dan depresi yang tinggi di masa pandemi pada remaja ini dapat disebabkan oleh berbagai faktor, seperti belum matangnya kemampuan siswa untuk mengekspresikan emosinya (Akat \& Karataş, 2020) dan kurangnya pengetahuan mengenai COVID-19 yang merupakan virus baru (Fitria \& Ifdil, 2020). Penelitian menunjukkan bahwa semakin banyak pengetahuan yang dimiliki terkait COVID-19 atau semakin puas individu akan informasi yang diperoleh mengenai pandemi, semakin rendah pula tingkat kecemasan atau depresi yang dialami (Maulida et al., 2020; Miranda et al., 2020).

Selain memberikan gambaran mengenai kondisi kesehatan mental siswa setelah 8 bulan menjalani PJJ (Maret-November 2020), penelitian ini juga mencoba menjelaskan aspek-aspek yang dapat menjadi sumber kecemasan atau depresi siswa melalui eksplorasi terhadap hal apa saja yang dirasa mengganggu bagi siswa. Hasil penelitian ini menunjukkan bahwa aspek yang paling dirasa mengganggu bagi siswa SMP dan SMA adalah terkait akademik dan interaksi sosial siswa, terutama dengan temannya. Secara rinci, kondisi akademik yang dirasa sangat mengganggu bagi siswa adalah meningkatnya perhatian siswa akan performa belajar yang mereka peroleh, peningkatan jumlah tugas, waktu pengerjaan tugas yang sempit, jadwal belajar serta sekolah, dan fasilitas belajar.

Hasil penelitian ini sejalan dengan berbagai penelitian lain yang dilakukan di awal pelaksanaan PJJ. Di mana, banyak siswa yang melaporkan berbagai keluhan serupa dengan dilaksanakannya PJJ, seperti jumlah tugas yang banyak dengan waktu pengerjaan yang singkat dan kurangnya penjelasan dari guru yang mempengaruhi pemahaman siswa akan materi (KPAI, 2020; Murhadi \& Ponidi, 2020; Oktawirawan, 2020; Wahana Visi Indonesia, 2020). Selain itu, terdapat kondisi unik yang umumnya terjadi pada siswa-siswa Asia. Tingginya ekspektasi dari orangtua dan lingkungan akan hasil belajar siswa juga akan memberikan tekanan tambahan bagi siswa (Tan \& Yates, 2011).

Hasil penelitian ini juga menunjukkan permasalahan teknis seperti sarana dan prasarana juga dikeluhkan oleh siswa sebagai salah satu aspek yang mengganggu dalam pelaksanaan pembelajaran secara daring. Di mana hal ini merupakan salah satu hal yang juga dilaporkan cukup banyak dikeluhkan oleh siswa (Murhadi \& Ponidi, 2020).

Selain itu, hasil penelitian ini juga menunjukkan bahwa aspek sosial, terutama interaksi dengan teman merupakan permasalahan lainnya yang menjadi cukup mengganggu bagi siswa. Penelitianpenelitian sebelumnya juga menunjukkan bahwa hubungan dengan teman sebaya menjadi 
permasalahan yang sering kali mempengaruhi kesehatan mental siswa (Anniko et al., 2019; Tan \& Yates, 2011). Dengan diberlakukannya kebijakan social distancing dan pembatasan aktivitas diluar rumah, membuat para siswa tidak bisa berinteraksi dengan teman-temannya seperti sebelumnya (Wahana Visi Indonesia, 2020).

\section{KESIMPULAN}

Melalui penelitian ini diketahui bahwa Para siswa mulai menunjukkan gejala kecemasan dan depresi yang bervariasi, mulai dari rendah hingga berat. Presentase terbesar adalah siswa SMP dan SMA yang mengalami gejala kecemasan dan depresi yang tergolong rendah, akan tetapi hal ini patut diwaspadai sebab akan sangat memungkinkan gejala ini akan meningkat jika tidak diberikan penanganan yang tepat. Adapun hal-hal yang diduga dapat menjadi sumber permasalahan kesehatan mental siswa dalam menjalani PJJ adalah permasalahan terkait akademik dan interaksi sosial dengan teman. Perubahan sistem belajar yang baru dan peningkatan jumlah tugas menjadi hal yang dirasa sangat mengganggu bagi siswa. Ditambah lagi dengan terbatasnya interaksi dengan teman yang selama ini menjadi salah satu aspek penting dalam perkembangan hidup di usia remaja.

Penelitian ini merupakan gambaran deskriptif terkait Kesehatan mental selama pandami dengan demikian belum mampu menjelaskan bagaimana perubahan yang dialami oleh siswa sebelum dan selama masa pandemic, ataupun faktor dari sumber kecemasan dan depresi siswa selama pandemic. Penelitian selanjutnya perlu menggali lebih jauh terkait faktor dari variabel serta kebutuhan akan penelitian longitudinal yang dapat menggambarkan hal ini secara lebih komprehensif perbandingan kondisi kesehatan mental siswa sebelum, selama dan setelah pandemi.

\section{DAFTAR PUSTAKA}

Akat, M., \& Karataş, K. (2020). Psychological Effects of COVID-19 Pandemic on Society and Its Reflections on Education. Journal of Turkish Studies, 15(4), 1-13. https://doi.org/10.7827/turkishstudies.44336

Ali, Q., \& Karyani, U. (2015). Identifikasi Jenis Layanan BK dalam Upaya Menjaga dan Meningkatkan Kesehatan Mental Siswa. Prosiding SEMNAS Penguatan Individu Di Era Revolusi Informasi, 363-376.

Anniko, M. K., Boersma, K., \& Tillfors, M. (2019). Sources of stress and worry in the development of stress-related mental health problems: A longitudinal investigation from early- to midadolescence. Anxiety, Stress and Coping, 32(2), 155-167. https://doi.org/10.1080/10615806.2018.1549657

Badan Pusat Statistik. (2019). Potret Pendidikan Indonesia 2019 (D. Susila, I. E. Harahap, \& R. Sinang (eds.)). Badan Pusat Statistik Indonesia.

Bernstein, G. A. (1991). Comorbidity and Severity of Anxiety and Depressive Disorders in a Clinic Sample. Journal of the American Academy of Child and Adolescent Psychiatry, 30(1), 43-50. https://doi.org/10.1097/00004583-199101000-00007

Budikayanti, A., Larasari, A., Malik, K., Syeban, Z., Indrawati, L. A., \& Octaviana, F. (2019). Screening of Generalized Anxiety Disorder in Patients with Epilepsy: Using a Valid and Reliable Indonesian Version of Generalized Anxiety Disorder-7 (GAD-7). Neurology Research International, 2019. https://doi.org/10.1155/2019/5902610

Fitria, L., \& Ifdil, I. (2020). Kecemasan Remaja Pada Masa Pandemi Covid -19. Jurnal 
EDUCATIO: Jurnal Pendidikan Indonesia, 6(1), 1. https://doi.org/10.29210/120202592

Johnson, R. B., \& Christensen, L. (2017). Educational Research: Quantitative, Qualitative, and Mixed Approaches (T. Accomazzo, J. Miller, R. Higgins, E. Helton, K. DeRosa, \& C. West (eds.); 6th editio). Sage Publication Inc.

Juliawan, I. W., Wiguna, D. G. E. S., \& Bawa, P. W. (2020). Persepsi Siswa Tentang Layanan Usaha Kesehatan Sekolah Jiwa Yang Diberikan Guru Bk Sma Negeri 1. Indonesian Journal of Educational Development, 1(2), 294-300.

Kementrian Kesehatan Republik Indonesia. (2018). Laporan Nasional Rikesdas 2018. In Badan Penelitian dan Pengembangan Kesehatan (p. 198). http://labdata.litbang.kemkes.go.id/images/download/laporan/RKD/2018/Laporan_Nasional RKD2018 FINAL.pdf

KPAI, T. (2020). "Survei Pelaksanaan Pembelajaran Jarak Jauh (PJJ) dan Sistem Penilaian Jarak Jauh Berbasis Pengaduan KPAI. ” kpai.go.id

Krejcie, R. V, \& Morgan, D. W. (1970). Determining Sample Size for Research Activities. Educational and Psychological Measurement, 38, 607-610. https://doi.org/https://doi.org/10.1177/001316447003000308

Kroenke, K., \& Spitzer, R. L. (2002). The PHQ-9: A New Depression Diagnostic and Severity Measure. Psychiatric Annals, 32(9), 509-515. https://doi.org/10.3928/0048-5713-2002090106

Larasati, L. A., Kristina, S. A., Pharmacy, C., Program, G., Pharmacy, F., \& Mada, U. G. (2020). Prevalence of depression symptoms among diabetes mellitus patients : A survey from primary care setting in Indonesia. 25(05), 2273-2280.

Lusi, C. K., Hogowiyono, P., \& Fuady, J. (2009). Pengebangan Sistem Pakar Untuk Mendiagnosis Gangguan Kesehatan Mental Peserta Didik di SMA Negeri 2 Malang.

Maulida, H., Jatimi, A., Heru, M. J. A., Munir, Z., \& Rahman, H. F. (2020). Depresi pada Komunitas dalam Menghadapi Pandemi COVID-19: A Systematic Review. Jurnal Sains Dan Kesehatan, 2(4), 519-524.

Miranda, D. M. de, Athanasio, B. da S., Oliveira, A. C. S., \& Simoes-e-Silva, A. C. (2020). How is COVID-19 pandemic impacting mental health of children and adolescents? International Journal of Disaster Risk Reduction, 51(August), 101845. https://doi.org/10.1016/j.ijdrr.2020.101845

Mubasyiroh, R., Suryaputri, I. Y., \& Tjandrarini, D. H. (2017). Determinan Gejala Mental Emosional Pelajar SMP-SMA di Indonesia Tahun 2015. Buletin Penelitian Kesehatan, 45(2), 103-112. https://doi.org/10.22435/bpk.v45i2.5820.103-112

Murhadi, M., \& Ponidi, P. (2020). Pembelajaran Online yang Efektif di Masa Pandemi Covid-19 Studi Kasus di SMP Negeri 4 Pakem Sleman. INTEK: Jurnal Informatika Dan Teknologi ..., 3. http://jurnal.umpwr.ac.id/index.php/intek/article/view/549

Nazari, N., Safitri, S., Usak, M., Arabmarkadeh, A., \& Griffiths, M. D. (2021). Psychometric Validation of the Indonesian Version of the Fear of COVID-19 Scale: Personality Traits Predict the Fear of COVID-19. International Journal of Mental Health and Addiction, 0123456789. https://doi.org/10.1007/s11469-021-00593-0

Oktawirawan, D. H. (2020). Faktor Pemicu Kecemasan Siswa dalam Melakukan Pembelajaran Daring di Masa Pandemi Covid-19. Jurnal Ilmiah Universitas Batanghari Jambi, 20(2), 541. https://doi.org/10.33087/jiubj.v20i2.932 
Onie, S., Kirana, A. C., Alfian, A., Mustika, N. P., Adesla, V., \& Ibrahim, R. (2020). Assessing the Predictive Validity and Reliability of the DASS-21, PHQ-9 and GAD-7 in an Indonesian Sample. PsyArXiv Preprints. https://doi.org/https://doi.org/10.31234/osf.io/eqcm9

Pusat Data dan Informasi Kementrian Kesehatan RI. (2019). Situasi Kesehatan Jiwa DI Indonesia. In InfoDATIN (p. 12).

Smith, T. E., Holmes, S. R., Sheridan, S. M., Cooper, J. M., Bloomfield, B. S., \& Preast, J. L. (2020). The Effects of Consultation-based Family-school Engagement on Student and Parent Outcomes: A Meta-analysis. Journal of Educational and Psychological Consultation, 00(00), 1-29. https://doi.org/10.1080/10474412.2020.1749062

Son, C., Hegde, S., Smith, A., Wang, X., \& Sasangohar, F. (2020). Effects of COVID-19 on College Students' Mental Health in the United States: Interview Survey Study. Journal of Medical Internet Research, 22(9), e21279. https://doi.org/10.2196/21279

Spitzer RL, Kroenke K, Williams JW, \& Löwe B. (2006). A brief measure for assessing generalized anxiety disorder: The GAD-7. Archives of Internal Medicine, 166(10), 1092-1097.

Suryaatmaja, D. J. C., \& Wulandari, I. S. M. (2020). Hubungan Tingkat Kecemasan Terhadap Sikap Remaja Akibat Pandemik Covid-19. Manuju: Malahayati Nursing Journal, 2(4), 820829.

http://www.tjyybjb.ac.cn/CN/article/downloadArticleFile.do?attachType=PDF\&id=9987

Tan, J. B., \& Yates, S. (2011). Academic expectations as sources of stress in Asian students. Social Psychology of Education, 14(3), 389-407. https://doi.org/10.1007/s11218-010-9146-7

Wahana Visi Indonesia. (2020). Seluruh Aspek Kehidupan Anak Terdampak Langsung Selama Pandemi COVID-19: Hasil Penilaian Cepat Wahana Visi Indonesia di 14 Provinsi. Wahana Visi Indonesia. http://repositorio.unan.edu.ni/2986/1/5624.pdf

WHO. (2020). Adolescent Mental Health. World Health Organization. https://doi.org/10.1007/978-1-137-00443-7_3 